Article

\title{
The Power of Personality in the Operation of the New Poor Law
}

\author{
Karen Rothery \\ School of Humanities, University of Hertfordshire, Hatfield AL10 9AB, UK; k.rothery2@herts.ac.uk
}

Received: 4 December 2019; Accepted: 15 January 2020; Published: 20 January 2020

\begin{abstract}
For many years, historians focused on the institutional aspects of the poor laws and the power vested in the central authorities; more recently, the experience of the poor themselves has been at the heart of academic study. This article looks at a third group: those who exercised power and influence in delivering poor law policy at a local level and specifically how certain individuals with strong personalities administered or disrupted what was heralded as a uniform and centrally controlled system. Based on an in-depth local history study on the development of the poor law unions in the county of Hertfordshire, England, this paper will look in detail at the contribution made by specific individuals during the early years of the new poor law and consider how they influenced poor law policy and practice. It will argue that personal contributions made a difference to the operation of the poor laws and that the personality of certain poor law officials had the potential to influence the central authorities, which has not been fully recognised. This research supports the argument that the new poor law was regionally diverse and provides new evidence to suggest that the power of local personnel to influence poor law policy contributed to that diversity and should not be overlooked.
\end{abstract}

Keywords: new poor law; poor law guardians; poor law administration; personality; workhouses

\section{Introduction}

Traditional poor law narratives have focused on the power of the policy makers, namely the Poor Law Commission (later the Poor Law Board and the Local Government Board). Through the power vested in their office by virtue of the Poor Law Amendment Act of 1834, the poor law commissioners and their influential secretary Edwin Chadwick sat in London and dictated policy to the provinces. Yet many other people were integral to the poor relief system. People were an essential element in the operation of the new poor law. People were recipients of poor relief; people administered the process of poor relief and people created policy around poor relief. These people, often in distinct social groups, and each with their own function to perform were interdependent but not equally so. None could exist without the presence of the others, yet within these groups different individuals exerted different levels of power at different times. In turn, this influenced their relationship with their co-dependants in the power and poverty dynamic. Historians have argued for agency among the poor themselves, but few have observed the power exerted among the middlemen, those at the heart of poor law administration. Most often, many of this middle tier of administrators are referred to as the collective body they represented, the Board of Guardians; yet each board was composed of up to 70 men. ${ }^{1}$ This article argues that at particular times, and in particular places, there were individual personalities who made a difference to both the implementation of and the operation of the poor laws.

1 There were no female guardians until 1875 when Miss Martha Merrington was elected in Kensington. 
Individuals involved in local poor law administration can be difficult to identify within official records which operate at the macro level and seek to present the appearance of an authority in control of policy and practice. The new bureaucracy created by the new poor law generated a vast archive of material which historians have been mining for information about the operation of the poor law over several generations. (Baxter 1841; Nicholls 1967a, 1967b; Webb and Webb 1910, 1929a, 1929b; Roberts 1960; Blaug 1963, 1964; Rose 1965, 1971, 1972; Poynter 1969; Edsall 1971; Longmate 2003; Oxley 1974; Fraser 1976; Brundage 1978, 2002; Digby 1978; Williams 1981; Crowther 1983; Crompton 1997; Englander 1998; Hollen Lees 1998; Kidd 1999; King 2000; King and Tomkins 2003; Driver 2004; Boyer 2006; Hurren 2007; Green 2010; Wallace 2010, Shave 2017). Within the archives are local records (usually found in county record offices) or locally specific national records (found in The National Archives) which provide evidence of those most active in poor law matters. ${ }^{2}$ This places regional and preferably local studies at the heart of accessing information, which demonstrate particular relationships and the influence individuals exerted over others in relation to poor law matters. This article takes a local history perspective and focuses on the period of the 1830s and 1840s in Hertfordshire and using examples of specific individuals with different roles within the poor law machinery demonstrates how individuals made a difference to the operation of the poor laws. It concludes by suggesting that there is more material to be found to enable further study of individual contributions which, in turn, may enhance our understanding of how the poor law operated. This is not a discussion of poor law policy per se, nor is it a discussion about pauper agency or a history from below, but a recognition of how individual people, some ordinary and some less so, were able to influence-both positively and negatively - the implementation and operation of the new poor law during its early years.

\section{Lord Salisbury and Policy Change}

Among the key players in this history were some members of elite society and one of the most distinguished was James Gascoyne-Cecil, the second Marquis of Salisbury. Lord Salisbury has been overlooked by scholars of poor law history and policy. Salisbury took considerable interest in the poor laws and the provision of poor relief in his own community: he chaired a House of Lords select committee into the poor laws in 1830, he took part in parliamentary debates and took action on his own estates. In 1820, he established a deterrent workhouse in the parish of Hatfield where his ancestral home Hatfield House was located. Notably, Salisbury set up his workhouse before Beecher and the Nottinghamshire reformers began their work in the more famous Southwell. Salisbury held meetings with and corresponded with Edwin Chadwick when the latter was working on the Royal Commission looking at the poor laws. The Hatfield workhouse master, John Bridgens, gave evidence to the Royal Commission in 1832 and 1833 as did the Reverend Francis Faithful, Rector of Hatfield. ${ }^{3}$ Salisbury's private correspondence indicates that Chadwick gave him advance access to final copies of the Poor Law Report. ${ }^{4}$ Chadwick and the Chairman of the Royal Commission examining the Poor Laws, Nassau Senior, coveted Salisbury's support for the Poor Law Bill in the House of Lords and as a result Salisbury used his influence to persuade Chadwick and Senior to make changes to the final bill to allow appeals to magistrates and more significantly to drop the controversial clause which would have outlawed all outdoor relief after July $1835 .{ }^{5}$ Without Lord Salisbury's intervention, it is possible that the original Poor Law Amendment Act would have been much harsher than it actually was.

Arguably it was not Lord Salisbury's personality but his elite status in society which gave him influence; but not all elite men of his standing took an active role in the management of poor law

2 For a detailed look at The National Archive holdings, see (Carter and Whistance 2011a).

Report from His Majesty's commissioners for inquiring into the administration and practical operation of the Poor Laws. British Parliamentary Papers, 1834 (44) XXVII-XXXIX. pp. 61-71.

4 Letter from Chadwick to Lord Salisbury, 18 February 1834, 2M/I/1/20/27, Hatfield House Manuscript Collection.

5 Letter from Unwin Heathcote to Lord Salisbury, 26 July 1834, 2M/I/1/22/20, Hatfield House Manuscript Collection. 
provision in the areas they controlled as major land or property holders. Salisbury was personally engaged in managing and reforming poor relief provision both before and after the passing of the new poor law. As well as setting up his deterrent style workhouse he regularly met with his local Rector to discuss and decide upon what poor relief should be offered to parishioners. He created work schemes to keep agricultural labourers employed in lean periods and, after the act was passed, he sat as chairman of the board of guardians. Lord Salisbury's influence was such that if he did not attend the board of guardians' meeting, any significant decisions were deferred until such time as he attended or had been consulted privately. Over time, his attendance at committee meetings became less regular and consequently decision making was often deferred, thus impeding the efficient running of the poor law administration in the Hatfield union. ${ }^{6}$ Lord Salisbury remained as the nominal head of the Hatfield poor law union until his death in 1868 . That his son and heir did not replace Salisbury as chairman of the Hatfield board of guardians offers further evidence that it was the person not his position or status that was most important in securing Lord Salisbury's engagement with the poor law. ${ }^{7}$

Salisbury also secured the appointment of one of the first assistant poor law commissioners. Daniel Goodson Adey was appointed as the assistant commissioner to aid the implementation of the new poor law in Bedfordshire and Hertfordshire; Adey's effusive letter of thanks showed he knew exactly who had secured his appointment from an extensive field of applicants. ${ }^{8}$ Salisbury was subsequently able to influence Adey regarding the composition of the Hatfield union and during his time in Hertfordshire Adey rarely visited the Hatfield union or interfered in its operation. ${ }^{9}$

The legacy of the second Marquis is clear; he used his personality and considerable interest in the operation of the poor law as well as his status as a member of the House of Lords to secure changes to the Poor Law Bill and he was key to the progress of the Poor Law Amendment Bill in the House of Lords. More significantly he was able to influence Prime Minister Earl Grey and Chairman of the Royal Commission Nassau Senior to concede the right of paupers to appeal decisions to the magistrates and to withdraw the fixed date for the ending of all outdoor relief and thus helped create a more munificent regime than might otherwise have been the case.

\section{Thomas Wilson-Financial Intervention}

Other more ordinary citizens had personalities which exerted power within the poor law administration. One of these was Thomas Wilson (1801-1843), a former vestry clerk and overseer of the poor in Rickmansworth who served as Workhouse Master and Relieving Officer for the Rickmansworth union from 1834 to 1843 . Wilson was highly regarded by his own board of guardians and by the assistant poor law commissioner Daniel Adey who described him as 'far too good to be a relieving officer' and attempted to recruit him as a trainer and instructor of other officers in the unions Adey was establishing. ${ }^{10}$ Wilson considered Adey's offer carefully but ultimately declined as he was committed to the task of eradicating pauperism in the Watford union. ${ }^{11}$ Had Adey succeeded in recruiting Wilson to this task, the competency of other officers might have been better. Nevertheless, Thomas Wilson set the standard by which others were judged by Adey. When the Watford union found itself with insufficient funds to pay the builder erecting the new workhouse, Wilson stepped in and loaned the union $£ 170$ of his own money, a significant sum to a man whose annual salary was $£ 100 .{ }^{12}$ Wilson was

6 Hatfield Board of Guardian Minutes, BG/HAT series from 1835. Hertfordshire Archives and Local Studies (Hereafter HALS). Letter from Lord Salisbury to Chadwick, 15 July 1847, Chadwick MSS Collection, File 790, ff.53-54. University College London.

7 The third Marquis went on to become Prime Minister of Great Britain three times.

8 Letters from Adey to Lord Salisbury, 3 Sept 1834, 2M/I/1/22/41 and 22 Sept 1834, 2M/I/1/22/46. Hatfield House Manuscript Collection.

9 Lord Salisbury to Adey, 10 May 1835, 2M///1/25/37, Hatfield House Manuscript Collection.

10 Assistant Poor Law Commissioner Correspondence, MH32/5, September and October 1835. The National Archives. (Hereafter TNA).

11 Assistant Poor Law Commissioner Correspondence, MH32/5, 15 Sep 1835, 27 Oct 1835, 28 Oct 1835. TNA.

12 Watford Board of Guardian Minute Book, 9 May 1837. BG/WAT/1, HALS. 
respected by both his managers and the poor. Following his sudden death whilst out distributing poor relief in 1843, a significant memorial was erected to him in the Rickmansworth parish churchyard and is inscribed:

To the memory of Mr. Thomas Wilson of this parish who departed this life September 12th 1843 Aged 42 years. He was for many years vestry clerk permanent overseer of this parish and subsequently relieving officer to the Watford Union and having uniformly discharged the duties of these important offices with zeal and fidelity he gained such general esteem and respect that when suddenly removed by death, his loss being universally and deeply deplored. This monument was raised to his memory by the voluntary contributions of this neighbourhood in testimony of the high appreciation of his important and valuable services and in order to perpetuate to succeeding generations the record of his worth. ${ }^{13}$

Wilson was a man committed to making the poor law work, examples of which include his funding the new workhouse and his commitment to his work in the community. His intervention, providing financial support to the local board, helped ensure the transition from the old to the new poor law progressed smoothly. His personal commitment to ensuring the new poor law was successfully implemented appears to have won him more friends than enemies and contributed to Watford union adopting the new poor law at the earliest opportunity. However, there were others who were equally committed to opposing the new poor law or disrupting its operation once enacted.

\section{Personality and Disruption of Poor Law Administration}

One such personality was Samuel Unwin Heathcote ${ }^{14}$, described as 'a stern unbending Tory who could be relied on to oppose innovation. He fought Catholic Emancipation, Parliamentary Reform, Rural Police and Railways' (Spicer 1984, p. 64.). Heathcote was vehemently opposed to the introduction of the Poor Law-more specifically the joining of his own parish of Shephall (where he had a large estate and was Lord of the Manor) with neighbouring parishes. Heathcote made his position clear in a letter to Lord Salisbury in which he objected to the setting up of the commission and urged the Lords to defer the bill 'for the sake of the country and their own sakes'. ${ }^{15}$

Heathcote did not personally participate in poor law administration, but he actively attempted to disrupt its proceedings by the elected guardians; in this, he was aided and abetted by his political ally Thomas Hailey an elected guardian who troubled meetings from within. That Heathcote had held power and influence locally was known to assistant commissioner Adey; when setting up the Hertfordshire unions, Adey attributed letters of objection to the formation of the Hitchin union as the work of Heathcote. However, the extent to which Heathcote was prepared to use his influence was underestimated by Adey. ${ }^{16}$ Heathcote lived in Shephall parish and was behind a campaign of non-cooperation and challenges to the poor law authorities.

Firstly, Shephall parish refused to elect a guardian and refused to cooperate with the newly formed board of guardians. ${ }^{17}$ When formally summoned to attend a board of guardians meeting and provide information, both the churchwarden John Pallett and the parish overseer Thomas Franklin gave vague and evasive responses which suggest that they were being as difficult as possible. ${ }^{18}$ As a result, the guardians took legal proceedings. The Poor Law Commission strongly advised the churchwardens

\footnotetext{
13 Memorial stone, St Mary the Virgin Churchyard, Rickmansworth, Hertfordshire. Find a Grave, https://www.findagrave.com/ memorial/142945249/thomas-wilson [accessed 22 April 2019].

14 Sometimes Samuel Unwin or Unwin-Heathcote.

15 Unwin Heathcote to Lord Salisbury, 26 July 1834, 2M/I/1/22/20, annotated with Lord Salisbury's draft reply, 2M/I/1/22/21. Hatfield House Manuscript Collection.

16 Letters from D G Adey, 10 May 1835 and 1 Jul 1835. MH 12/4612, TNA.

17 Letter from Pallett and Chalkley, 24 Jul 1835. MH 12/4612, TNA.

18 Hitchin Board of Guardians Minute Books, 13 Jul 1835 and 20 Jul 1835. BG/HIT/1, HALS.
} 
and overseers of Shephall to comply with their legal obligations to the Hitchin board of guardians. ${ }^{19}$ But the response was defiant.

The Rate Payers of the Parish of Shephall contest that not having appointed any Guardian nor joined any union they are not bound to place their properties at the disposal of a Board on which they are not represented. That the rates of the Parish are low and that there are no labourers out of employ and also they therefore can reap no benefit but that the parochial charges will be increased in their case by joining any union which they believe can neither be the object of the law nor the intention of the Commissioners. They therefore wish to be let alone to disburse their own outgoings and also their own affairs. ${ }^{20}$

This letter, signed by churchwardens Pallett and Chalkley, contained no opening greeting and ended without the customary pleasantries. The poor law commissioners supported the Hitchin board and warned the parish of Shephall of the penalties they faced by non-compliance. ${ }^{21}$ This was early days for the new poor law and the Poor Law Commission was keen to quash any resistance. There was no doubt that Heathcote was behind this resistance from the Shephall parish. ${ }^{22}$

When legal proceedings against the parish officers began in August 1835 the case was heard at St Albans Petty Sessions and Heathcote acted as Barrister for the parish officers. He raised 'numerous frivolous objections', before the parish officers were convicted of 'non-payment of their Quota as ordered by the guardians. ${ }^{23}$ They were fined $£ 5$ with costs of $£ 1$ and 3 shillings. Adey reported that Heathcote's 'language was violent and little credit to him, particularly considering his station in this County. ${ }^{24}$ Heathcote remained defiant and threatened to take the matter to the King's Bench if necessary; he paid the fine but Shephall did not pay the quota to the union as ordered. Further legal proceedings ensued, there was a second fine of $£ 10$ and another order for payment to be made. ${ }^{25}$ At the first hearing Heathcote said he was willing to go to prison rather than see the parish of Shephall join the Hitchin union and claimed he would leave the country if he failed to stop it. ${ }^{26}$ But continuing this action exposed the parish officers, not Heathcote, to prison if they failed to comply and obey the law. Heathcote did not pay the second fine and nor did the churchwardens; ultimately, the Hitchin board instructed solicitors to recover the quota and the prosecution costs incurred by the union. ${ }^{27}$ These costs were all passed back to the rate payers of Shephall parish, which of course included Heathcote and his churchwarden and overseer. ${ }^{28}$

Defeated in the courts, Heathcote changed his tactics; first, he attended a board of guardians meeting and demanded to know how the parish quota of $£ 11$ was calculated. Next, he tried to disrupt the operation of the board of guardians; he threatened one of his tenants John Horn with eviction if he continued as a guardian. Horn, the elected guardian for Little Wymondley, presumably in fear of his livelihood, complied, resigned and attended no further meetings after September $1835 .{ }^{29}$ Both Adey and the chairman of the Hitchin board, Rev. Sullivan reported this event to the Poor Law Commission but none could prevent this abuse of power by a local landowner. ${ }^{30}$

19 Draft letter to the Churchwardens and Overseers, Shephall, 22 Jul 1835 and draft letter to Hitchin Union 23 Jul 1835. MH $12 / 4612$, TNA.

20 Letter to the Poor Law Commissioners, 24 Jul 1835. MH12/4612, TNA.

21 Letter from PLC, 27 Jul 1835. MH 12/4612, TNA.

22 Hitchin Board of Guardians Minute Book, 3 Aug 1835, BG/HIT/1, HALS and Reports from Adey, 4 and 8 Aug 1835. MH 12/4612, TNA

23 Hitchin Board of Guardians Minute Books, 10 Aug 1835. BG/HIT/1, HALS

24 Report from Adey, 8 Aug 1835. MH 12/4612, TNA

25 Hitchin Board of Guardians Minute Books, 21 Sep 1835. BG/HIT/1, HALS

26 The Reformer, 25 Aug 1835, p. 3.

7 Hitchin Board of Guardians Minute Books, 28 Dec 1835. BG/HIT/2, HALS

28 Quarterly abstract of accounts and report from William Bentley, Auditor, 23 Feb 1836. MH 12/4612, TNA

29 Letter from The Rev. Frederick Sullivan, 28 Sep 1835. MH 12/4612, TNA and Hitchin Board of Guardians Minute Books, 5 Oct 1835 . BG/HIT/2, HALS.

30 Letter from Adey, 3 Oct 1835 MH 33/5, TNA and Letter from The Rev. Frederick Sullivan, 28 Sep 1835. MH 12/4612, TNA. 
Heathcote succeeded in temporarily disrupting the work of the board of guardians but proceedings against the parish stopped when Shephall paid their quota in October 1835. ${ }^{31}$ The local press raised questions about Heathcote's behaviour and suggested he had taken his opposition to the poor law beyond the bounds of reasonableness for a man in his position; as a Commissioner of the Peace and head of the local yeomanry, it was suggested that he had gone too far in encouraging violent agitation. Not only did he lack the support of his peers, some of the newspaper articles questioned his mental health. ${ }^{32}$

Heathcote continued to campaign against unionisation. Having failed twice in the courts to win the argument about parish contributions, his next tactic was to claim that Shephall had been placed in the wrong union. Following a personal meeting with George Nichols, one of the poor law commissioners, a formal application was tendered for the parish to be released from the Hitchin union and placed in the Welwyn union. Unsurprisingly perhaps, given all the disruption stirred up by Heathcote, the Hitchin guardians immediately agreed to release Shephall from the union. ${ }^{33}$ The poor law commissioners, not keen to have their authority challenged and not wishing to set a precedent for future applications of this nature, refused the move on the grounds it was not supported by the unions. Heathcote knew the Hitchin guardians had been in favour and so challenged this decision and he accused the Poor Law Commission of ignoring the facts, double-dealing and deliberately misleading and deceiving the people of Shephall. ${ }^{34}$ It was not the Hitchin guardians who had declined the move, but the Welwyn guardians who were unwilling to accept him. poor law commissioner Frankland Lewis informed Heathcote that the Welwyn union had 'without a moment's hesitation expressed the most earnest and decided wish that it may on no account be done' and in a particularly frank concluding paragraph stated ' $\mathrm{t}$ ] he only conclusion which as a matter of business I can draw from them is that the Guardians of Welwyn union were abundantly justified in the reluctance they showed to any union with your Parish, and that we decided correctly in protecting them from it'. ${ }^{35}$ Despite Heathcote's campaign of protest Shephall remained part of the Hitchin union and in subsequent years elected a guardian to join the board.

Heathcote had power in his own community by virtue of his position as a major landholder, lord of the manor, magistrate and head of the local yeomanry, but his objectionable personality and bellicose behaviours alienated many and worked against him securing his objectives. Repelling his protracted protests was time-consuming and distracting and demonstrates how just one eccentric character forced the poor law commissioners and local guardians to adopt policies to push back against attempts to disrupt the implementation and operation of the new poor law.

Another Hitchin personality who impeded the smooth running of the Hitchin board was Heathcote's political ally, a fellow 'Ultra Tory' Thomas Hailey, a tenant farmer with one of the largest farms in the district. (Spicer 1984, p. 64). Hailey sat as one of four guardians for the parish of Hitchin from 1835 to 1857 and was Vice-Chairman of the Hitchin board for its first six years. ${ }^{36}$ He was described by the workhouse master John Manning, as 'one of our most influential guardians' and by assistant commissioner Adey 'as a most violent person and a political friend of Mr Heathcote's' ${ }^{37}$

Like Heathcote, Hailey failed to endear himself to his peers. A letter, penned by 'A Guardian' was sent to the local newspaper in October 1840 complaining about Hailey's behaviour:

... his conduct at the board is extremely irregular and objectionable, tending to bring the whole body discredit with the public, and greatly impair its efficiency. Disgusted with the party spirit and violence that prevails, many guardians at present absent themselves, and it

\footnotetext{
Hitchin Board of Guardians Minute Books, 5 Oct 1835. BG/HIT/2, HALS.

The Reformer, 6 Oct 1835, p. 2; 13 Oct 1835, p. 2-3; 20 Oct 1836, p. 2.

Hitchin Board of Guardians Minute Books, 25 April 1836. BG/HIT/2, TNA.

Letter from Heathcote, 5 Jul 1836. MH 12/4612, TNA.

Draft letter to Heathcote, 27 Jul 1836. MH 12/4612, TNA.

Hitchin Board of Guardians Minutes, BG/HIT/1 to BG/HIT/16

Deposition of John Manning, 7 Aug 1840. MH 12/4613, TNA. Letter from D G Adey, 10 May 1835. MH 12/4612, TNA.
} 
is with difficulty that enough are found to constitute a board.... even his own followers appear tired with his restless spirit of agitation. ${ }^{38}$

Hailey's manner combined with his regular presence at board meetings probably contributed to guardians in the Hitchin union having some of the lowest attendance rates. In 1836/37 there were 39 guardians in the Hitchin union. Attendance rates ranged from four to 23 guardians per meeting with a mean attendance of 11.1 guardians (28.5\%). In the nearby Hertfordshire unions of Hatfield, St Albans and Watford attendance rates were $40 \%, 49 \%$ and $33 \%$ respectively. Hailey attended $77 \%$ of all meetings. In the year 1840/41 (when a fellow guardian wrote to The Reformer), he attended over 83\% of the meetings - the highest attendance of any guardian on the Hitchin board that year. Other scholars have highlighted poor attendance by guardians and the difficulties this caused. However, none have considered that it was the personality of individual guardians that might be keeping others away. (Rose 1965; Thompson 1988; Hooker 2013). Hailey tried to use his position as vice-chairman to control the board of guardians' meetings and drive the agenda. In 1840, there were a series of complaints, accusations and counter accusations, stirred up by Hailey, against the workhouse master John Manning and the schoolmaster Thomas Simpson which resulted in both Manning and Simpson being dismissed. But Manning found sympathetic supporters among members of the board of guardians and local rate payers who lobbied the Poor Law Commission in his favour. A petition signed by 120 rate-payers was sent to the poor law commissioners stating the order dismissing John Manning from his office has been received with a general feeling of surprise and regret and has excited the public sympathy strongly in his favour'. ${ }^{39}$ Whilst discussions were still ongoing to save Manning, a man for whom Hailey had previously acted as surety, Hailey lobbied against him, and pressed the guardians to advertise Manning's post. Hailey's power to control events was evidenced by another Hitchin guardian William Lucas who claimed that Hailey had tried to pack the board meeting with his own supporters by writing to selected guardians some of whom had 'never taken any part in the proceedings of the Board'. ${ }^{40}$ In so doing, Hailey was able to exert great control at board meetings; however, the following year he was defeated on a show of hands for re-election to the vice-chairman's position; he was replaced as vice-chairman but continued to serve as an elected guardian and to regularly attend board meetings. ${ }^{41}$

\section{Personality and Position}

Hailey had impact because of his personality, which was driven to disrupt the operation of the poor laws, but he also had impact because of his position as vice-chairman. In the Hitchin union, the board of guardians installed both the chairman and vice-chairman on all of the union's subcommittees (of which there were many covering different aspects of poor law administration) thus Hailey had the potential to be closely involved in all aspects of the union's management of the poor. In her study of the crusade against out-relief in the in the last quarter of the nineteenth century, Elizabeth Hurren suggested that the presence of a dominant personality on the board of guardians was a significant factor in the crusading cause championed by Brixworth union in Northamptonshire. (Hurren 2007, p. 257). Indeed, she identifies Albert Pell, the 5th Earl Spencer and William Bury as 'the three crusading zealots' who in combination developed a strategy to eradicate all out-relief in the Brixworth union after 1873. (Hurren 2007, p. 108). More recently, new research by Nicola Blacklaws has discussed how the Blaby union regularly rotated key positions across the members of a large board. (Blacklaws 2019, p. 64). However, this contrasted with her findings in the Newcastle union where she found that a popular chairman, Mainwaring, had held office continuously from 1894 to 1927, during which time he was challenged only once. (Blacklaws 2019). Indeed, Mainwaring was the successor to his father and

\footnotetext{
38 The Reformer, 31 Oct 1840, p. 2.

39 Petition from Hitchin rate-payers to the Poor Law Commissioners, [undated but received by Poor Law Commission 20 Nov 1840]. MH 12/4613, TNA.

40 Letter from Lucas to PLC, 21 Jan 1841. MH 12/4614, TNA.

41 Hitchin Board of Guardians Minute Books, 30 Mar 1841. BG/HIT/6, HALS.
} 
grandfather who between them had served as the chairman of the union in an unbroken run from its inception in 1838. (Blacklaws 2019, p. 119). Are these post holders in office by virtue of their family's position in the community or the force of their own personality? Geoff Hooker has also made the case for the high-attending and long-serving John Lewis of the Llandilofawr union in Wales controlling union affairs using an established 'network of local personal connections' to become the 'de-facto prime mover in all union affairs' (Hooker 2013, p. 172).

Outside of the board of guardians, other poor law officers and contactors had the potential to impact on the operation of the new poor law. Perhaps none more so than the union medical officers. Historians hold differing opinions about the impact of the new poor law on medical care; some favour an expansion of medical care as an unplanned consequence of the new poor law and others see it as a catalyst for a decline in the scale and standard of medical care. (Flinn 1976, pp. 45-66; Reinarz and Schwarz 2013, p. 10; Price 2015, p. 10). Scandals of neglect are a familiar trope to poor law scholars; less time has been taken to explore the positive actions on the part of poor law officers. Certainly, such examples are fewer in number, but there are occasional examples of guardians or poor law officers improving conditions for paupers. This is perhaps most visible when examining actions of some medical officers who by force of personality pushed through some marginal changes with limited resources or stood up to the actions of the local board of guardians in order to improve the lot of those in their care.

Oswald Foster was one of seventeen doctors who served in the Hitchin union between 1835 and 1847. Throughout this period Foster and his son were responsible for the Hitchin union workhouse. In December 1841 Foster wrote to the board of guardians concerned about the crowded state of the workhouse and the spread of contagious diseases. In January 1842 (whether by coincidence or because of some prior knowledge), the Poor Law Commission requested a report from Foster asking him to specify the number the workhouse could accommodate consistent with 'health or sufficient ventilation' ${ }^{42}$ The doctor's report painted a picture of significant overcrowding and unpleasant conditions. ${ }^{43}$ He calculated the Hitchin workhouse was suitable for about 200 people although it contained beds for 260 and, earlier that year, it had housed 350 paupers. Foster reported that 33 elderly women occupied a day room that measured 16 feet by 22 feet $(4.9 \mathrm{~m}$ by $6.7 \mathrm{~m})$ and children slept six or seven to a bed. ${ }^{44}$ He also recommended the workhouse should have separate accommodation which would allow for appropriate treatment of paupers who were ill and a separate ward for midwifery cases. ${ }^{45}$ The Hitchin board of guardians believed that Foster 'looked upon the Workhouse rather with respect to its fitness as an Infirmary than a place for the reception of paupers' and wrote to the commissioners to express their dissatisfaction with Foster's report. ${ }^{46}$ The poor law commissioners ultimately sanctioned the workhouse as fit for 240 inmates and the separate school house as suitable to house a further 80 children. ${ }^{47}$ Nevertheless, improvements in capacity were made to the Hitchin workhouse with extensions and alterations over the next five years. The argument over capacity was re-awakened in August 1847 when a new report by Foster put the capacity at 340 (based on the cubic capacity of air required by each sleeper). ${ }^{48}$ Once again, the guardians disagreed and compiled a separate inventory which listed the capacity of various wards and dormitories and increased the capacity to 405 inclusive of 14 infants or children. ${ }^{49}$ The Poor Law Commissioners' Annual Report published in 1847 put the capacity at just $300 .^{50}$ If this number was enforced by the guardians, this would have lessened the overcrowding issue at least for the workhouse paupers of Hitchin.

42 Hitchin Board of Guardians Minute Books, 25 Jan 1842. BG/HIT/6, HALS

43 Hitchin Board of Guardians Minute Books, 15 Feb 1842. BG/HIT/6, HALS.

44 Hitchin Board of Guardians Minute Books, 15 Feb 1842. BG/HIT/6, HALS.

45 Hitchin Board of Guardians Minute Books, 15 Feb 1842. BG/HIT/6, HALS

46 Hitchin Board of Guardians Minute Books, 15 Feb 1842. BG/HIT/6, HALS

47 Hitchin Board of Guardians Minute Books, 15 Feb 1842 and 22 Feb 1842. BG/HIT/6, HALS.

48 Hitchin Board of Guardians Minute Books, 17 Aug 1847. BG/HIT/10, HALS.

49 Hitchin Board of Guardians Minute Books, 31 Aug 1847. BG/HIT/10, HALS.

50 Thirteenth Annual Report of the Poor Law Commissioners, British Parliamentary Papers, (1847) 816, XXVIII.I, Vol. 28, p. 166 
The medical officer in Watford Thomas Able Ward (1795-1862) failed to persuade his board of guardians that the workhouse was significantly overcrowded but he was permitted to introduce sulphur baths as part of his treatment regime for scabies (commonly referred to as 'the itch'). ${ }^{51} \mathrm{He}$ wanted to extend the facility to outdoor paupers and also suggested that those on out-relief should be permitted to take a bath in the workhouse for a small fee and although the guardians agreed, the Poor Law Commission refused permission for the workhouse to be used in this way. ${ }^{52}$ Ward was, however, allowed to increase the quantity of meat in the diet of elderly and infirm paupers. ${ }^{53}$

Similarly, the St Albans medical officer John Thomas Lipscomb (1796-1869) was able to persuade the guardians there to change the dietary for the children and to allow them to take a walk outside of the workhouse two or three times per week. ${ }^{54}$

These were small successes which might have reduced some of the worst conditions for the poor. They were changes initiated by individuals not by committees of guardians or commissioners. They suggest that there were some pockets of compassion for the poor alongside a professional desire to improve public health.

\section{Conclusions}

Poor law history should not just focus on policy and the metrics surrounding that policy, but it should also recognise the people within the system and how they experienced, contributed to, changed and influenced a policy which elsewhere has been described as one of the most important pieces of social legislation ever passed. (Englander 1998). The men cited in the examples above represent just a small sample of the thousands of men who served as guardians or were otherwise involved in poor law administration but they all made a difference to the implementation and the operation of the poor law as a result of who they were. They came from different backgrounds and had different roles within the poor law administration, but each made a contribution to the poor law locally (and in Salisbury's case nationally too). Finding evidence of these activities requires close reading of the surviving archival sources specific to the poor law. Further information may be gleaned from newspaper accounts of poor law proceedings and sometimes in ego documents in which an individual has documented their life. However, involvement in poor law administration is often transitory; it is not usually a primary occupation and in the case of rural parishes may represent an affiliation to a union whose administrative centre was some distance away. Evidence of working in poor law affairs is unlikely to appear in the vital documents that form the cornerstone of biographical research such as census records, birth, marriage and death records or wills. It is in the poor law records held in local archives and the locally specific records at The National Archives that we are most likely to see the intimate workings of poor law administration and the people engaged in it. The increased availability online and the indexation of local records in county record offices and projects at a national level such as the digitization of some MH12 records by The National Archives is improving accessibility to the locally specific records needed to identify individual office holders. ${ }^{55}$ The ongoing project 'In Their Own Write' led by Steve King and Paul Carter is identifying hundreds of examples of pauper correspondence with the poor law authorities and the nature of that correspondence means that significant numbers of poor law administrators will be named and identified through those letters. ${ }^{56}$ In turn, this could be

\footnotetext{
Watford Board of Guardians Minute Books, 6 Aug 1841. BG/WAT/3, HALS

Watford Board of Guardians Minute Books, 3-10 Dec 1845. BG/WAT/6, HALS.

Watford Board of Guardians Minute Books, 26 Nov 1845. BG/WAT/6, HALS.

4 St Albans Board of Guardians Minute Books, 15 Feb 1839. Off Acc 1182, HALS.

55 The correspondence files between 24 local unions and the Poor Law Commission/Poor Law Board have been digitised and catalogued by The National Archives. For a full list, see http://www.nationalarchives.gov.uk/help-with-your-research/ research-guides/poverty-poor-laws/ [Accessed 28/06/19]. See also (Carter and Whistance 2011b).

56 'In Their Own Write' is a project run jointly by The National Archives (TNA) at Kew and the Department of History at the University of Leicester and funded by AHRC. The project uses letters from paupers and other poor people, and associated manuscript material such as petitions, sworn statements and advocate letters (those written on behalf of paupers) to investigate the lives of the poor between 1834 and 1900. The majority of work focuses on the many
} 
used to help identify key figures or personalities within the local administration. This may also be a route into targeted research of individuals in other resources, which could provide further insight into their personality and motivations for involvement on poor law matters in the communities they served. We know from other studies that there was regional variation in the operation of the poor laws. (Snell 1987; King 2000; Reay 2002). However, should we also ask to what extent did the personality and presence of one or two individuals make a difference to the operation of the poor law in addition to any socio-economic, cultural or political factors at work in a given area?

Comparative studies of other Boards of Guardians, in other parts of England and Wales, would further test to what extent particular individuals were able to influence poor law policy at the local and national level. Further research into individual contributions later in the nineteenth century, once the new poor law was more established, might also reveal whether or when the Boards accepted the authority of the central boards without question or whether the successful implementation of central policy at a local level was dependant on the cooperation of local men of influence. People were at the heart of the poor law, both as recipients and administrators, and the case studies presented here demonstrate that those with big personalities could, and did, make a difference to how the new poor law operated especially within a local context.

Funding: This research was undertaken as part of an AHRC funded doctoral scholarship with University of Hertfordshire in collaboration with Oxford Brookes University. This research was funded by the Arts and Humanities Research Council award number 1375753.

Conflicts of Interest: The author declares no conflict of interest.

\section{References}

Baxter, George Robert Wythen. 1841. The Book of the Bastiles: Or, The History of the Working of the New Poor Law. London: J. Stephens.

Blacklaws, Nicola. 2019. The Twentieth-Century Poor Law in the Midlands and Wales, c.1900-1930. Ph.D. thesis, University of Leicester, Leicester, UK.

Blaug, Mark. 1963. The myth of the old poor law and the making of the new. The Journal of Economic History 23: 151-84. [CrossRef]

Blaug, Mark. 1964. The poor law report reexamined. The Journal of Economic History 24: 229-45. [CrossRef]

Boyer, George R. 2006. An Economic History of the English Poor Law, 1750-1850. Cambridge: Cambridge University Press.

Brundage, Anthony. 1978. The Making of the New Poor Law: The Politics of Inquiry, Enactment, and Implementation, 1832-1839. London: Hutchinson.

Brundage, Anthony. 2002. The English Poor Laws 1700-1930. Basingstoke: Palgrave.

Carter, Paul, and Natalie Whistance. 2011a. Living the Poor Life: A Guide to the Poor Law Union Correspondence c1834-1871 Held at the National Archives. Salisbury: British Association for Local History.

Carter, Paul, and Natalie Whistance. 2011b. The poor law commission: A new digital resource for nineteenth-century domestic historians. History Workshop Journal 71: 29-48. [CrossRef]

Crompton, Frank. 1997. Workhouse Children. Stroud: Sutton.

Crowther, Margaret Anne. 1983. The Workhouse System 1834-1929: The History of an English Social Institution. London: Methuen.

Digby, Anne. 1978. Pauper Palaces. London: Routledge \& Kegan Paul.

Driver, Felix. 2004. Power and Pauperism: The Workhouse System, 1834-1884. Cambridge: Cambridge University Press.

Edsall, Nicholas C. 1971. The Anti-Poor Law Movement, 1834-1844. Manchester: Manchester University Press.

Englander, David. 1998. Poverty and Poor Law Reform in Britain: from Chadwick to Booth 1834-1914. London: Longman.

thousands of volumes of poor law correspondence (MH12) held by TNA, much of which has been little used by historians. https://intheirownwriteblog.com/about/ [Accessed 28/06/2019]. 
Flinn, Michael W. 1976. Medical services under the new poor law. In The New Poor Law in the Nineteenth Century. Edited by Derek Fraser. London: Macmillan, pp. 45-66.

Fraser, Derek, ed. 1976. The New Poor Law in the Nineteenth Century. London: Macmillan.

Green, David R. 2010. Pauper Capital: London and the Poor Law, 1790-1870. Farnham: Ashgate.

Hollen Lees, Lynn. 1998. The Solidarities of Strangers, The English Poor Laws and the People, 1700-1948. Cambridge: Cambridge University Press.

Hooker, Geoff. 2013. Llandilofawr Poor Law Union, 1836 to 1886: 'The Most Difficult Union in Wales'. Ph.D. thesis, University of Leicester, Leicester, UK. Unpublished.

Hurren, Elizabeth T. 2007. Protesting about Pauperism: Poverty, Politics and Poor Relief in Late-Victorian England, 1870-1900. Woodbridge: Boydell \& Brewer Ltd., vol. 60.

Kidd, Alan. 1999. State, Society and the Poor in Nineteenth-Century England. Basingstoke: Macmillan.

King, Steven. 2000. Poverty and Welfare in England, 1700-1850: A Regional Perspective. Manchester: Manchester University Press.

King, Steven, and Alannah Tomkins, eds. 2003. The Poor in England, 1700-1850: An Economy of Makeshifts. Manchester: Manchester University Press.

Longmate, Norman. 2003. The Workhouse: A Social History. Pimlico: Random House. First Published 1974.

Nicholls, George. 1967a. A History of the English Poor Law. London: Frank Cass \& Co., vol. I. First Published 1854.

Nicholls, George. 1967b. A History of the English Poor Law. London: Frank Cass \& Co., vol. III. First Published 1854.

Oxley, Geoffrey W. 1974. Poor Relief in England and Wales: 1601-1834. Newton Abbott: David \& Charles.

Poynter, John Riddoch. 1969. Society and Pauperism: English Ideas on Poor Relief, 1795-1834. London: Routledge and Kegan Paul.

Price, Kim. 2015. Medical Negligence in Victorian Britain: The Crisis of Care under the English Poor Law c1834-1900. London: Bloomsbury.

Reay, Barry. 2002. Microhistories: Demography, Society and Culture in Rural England, 1800-1930. Cambridge: Cambridge University Press.

Reinarz, Jonathan, and Leonard Schwarz, eds. 2013. Medicine and the Workhouse. Rochester: University of Rochester Press.

Roberts, David. 1960. Victorian Origins of the British Welfare State. New Haven, Conn.: Yale University Press.

Rose, Michael E. 1965. The Administration of the Poor Law in the West Riding of Yorkshire 1820-1855. Ph.D. thesis, Oxford University, Oxford, UK.

Rose, Michael E. 1971. The English Poor Law, 1780-1930. Newton Abbot: David \& Charles.

Rose, Michael E. 1972. The Relief of Poverty, 1834-1914. London: Macmillan.

Shave, Samantha A. 2017. Pauper Policies: Poor Law Practice in England, 1780-1850. Manchester: Manchester University Press.

Snell, Keith D. M. 1987. Annals of the Labouring Poor: Social Change and Agrarian England, 1660-1900. Cambridge: Cambridge University Press.

Spicer, C. M. 1984. Tyme out of Mind: The Story of Shephall near Stevenage in Hertfordshire. Luton: C. M. Spicer. and D. M. de Salis.

Thompson, Kathryn. 1988. The Leicester Poor Law Union, 1836-1871. Ph.D. thesis, University of Leicester, Leicester, UK.

Wallace, Eileen. 2010. Children of the Labouring Poor: The Working Lives of Children in Nineteenth-Century Hertfordshire. Hatfield: University of Hertfordshire.

Webb, Sidney, and Beatrice Webb. 1910. English Poor Law Policy. London: Longmans.

Webb, Sidney, and Beatrice Webb. 1929a. English Poor Law History Part II: The Last Hundred Years, Vol. I. London: Longmans.

Webb, Sidney, and Beatrice Webb. 1929b. English Poor Law History Part II: The Last Hundred Years, Vol. II. London: Longmans.

Williams, Karel. 1981. From Pauperism to Poverty. London: Routledge and Kegan Paul.

(C) 2020 by the author. Licensee MDPI, Basel, Switzerland. This article is an open access article distributed under the terms and conditions of the Creative Commons Attribution (CC BY) license (http://creativecommons.org/licenses/by/4.0/). 